DOI: $10.15642 / J I I S .2016 .10 .2 .237-260$

\title{
RELIGIOUS ATTITUDES OF THEOLOGICAL TRADISIONALIST IN THE MODERN MUSLIM COMMUNITY Study on Tahlilan in Kotagede
}

\author{
Sangkot Sirait \\ UIN Sunan Kalijaga, Yogyakarta - Indonesia | sangkot_sirait@yahoo.co.id
}

\begin{abstract}
In modernist Islamic thoughts, anything that comes from tradition, and that does not have any justiable ground in the Islamic law, must be abandoned since it is considered as heresy. However, a totally opposite situation occurs in Kotagede. Tablilan, one of those forbidden traditions, has been widely practiced by modernist Muslims. This paper attempts to examine the religious behavior of modernist community in Yogyakarta, especially with regard to motives and functions of their participation in tablilan. Using Emil Durkheim's sociological approaches, namely social solidarity and functionalism, the research result shows that the tradition of tablilan remains present amongst the modernist Muslim society in Kotagede due to three factors, these are, because of tolerance values and accommodative attitudes that they hold, the cultural aspects passed on from generation to generation, and the social needs. These three aspects can incorporate in each individual, and sometimes are only partially. It depends on the value system adopted by each individual. Furthermore, maintaining social role and status also becomes another factor that the tradition of tablilan could be kept alive and preserved until now.
\end{abstract}

Keywords: Tablilan, Nahdlatul Ulama, Yogyakarta, Bid'ah

\section{Introduction}

This paper discusses the tradition of tablilan, a form of culturalreligious ritual, performed by some of the community in Kotagede, 
Yogyakarta. The interesting part of this research is that tablilan occurs among modernist Muslim, Muhammadiyah, which strongly opposes tablilan. According to Muhammadiyah, tablilan tradition is another form of Hindu tradition which is still practiced by some Islamic communities. Muhammadiyah teaching standards consider tablilan tradition as a heresy, because there is no references in the genuine teaching of Islam regarding to this. ${ }^{1}$ The research describes the community of Kotagede who carry out tablilan and analyzes it from two perspectives, namely religion and social solidarity.

Tablilan is a word derived from Arabic "ballala-yuballilu-tablilan", which means the utterance of "Là iläha illa Alläh." When this sentence is spoken together in group as part of a special ritual during certain events by the society, then the word tablil changes into tablilan. Tablilan doesn't only mean saying the phrase "Là iläha illa Alläb" together in a group, but it also means that it is part of a community's activity related to certain specific events such as birth, death, and thanksgiving to Allah. Denny states that Tauhhid is not merely a matter of theological propositions, but also a living realization: the "making one" of God by total submission and service. ${ }^{3}$ Muhammadiyah doescnot specifically forbid tablil, but it opposes tablilan as people's tradition. There are several reasons why Muhammadiyah opposes tablilan: firstly, there is a special intention which usually becomes the main objective, namely sending pabala (reward) to the deceased, serving food, reciting prayers and reading the Holy Scripture; secondly, this activity is considered to be a legacy of Hindu tradition; thirdly, there is no solid ground base for this activity to be observed in the true teachings of Islam, either from al-Qur'an or from tradition of the Prophet (sunnab). ${ }^{4}$

\footnotetext{
${ }^{1}$ Mitsuo Nakamura, The Crescent Arises over the Banyan Tree, a study of the Muhammadiyah Movement in a Central Javaness Town, c. 1910-2010, 2nd Enlarged Edition (Singapore: ISEAS, 2012), p. 322.

2 Muhammad Abdul Fattah, Tradisi Orang-Orang NU (Yogyakarta: Pustaka Pesantren, 2012), p. 276.

${ }^{3}$ Frederick M. Denny, "Islamic Ritual Perspective and Theories," in Richard C. Martin (ed.), Approaches to Islam in Religious Studies (Tucson: The University of Arizona Press, 1985), p. 64.

${ }^{4}$ A discussion on rejection by two Islamic organizations, Muhammadiyah and PERSIS, against traditions of slametan and tablil, among others, can be read from Ahmad Haris, Bid'ab dalam Literatur Islam (Jambi: Referensi, 2007).
} 
This research aims to give a description of the reason why the tradition of tablilan persists in Kotagede society, to explore what are in the minds of those involved in tablilan, and to motivate others to join this activity. To better understand the tradition of tablilan in Kotagede society, this research uses Emile Durkheim's theory about religion and social solidarity. Aside from that, this research also uses Durkheim's theory of functionalism which views religion as one of the important social institutions catering to the society's most basic needs, and considering that one symptom or an activity in the society is never separated from other aspects. Durkheim's sociological perspective is interesting because it emphasizes on the importance of religious practices for the maintenance of social group.

\section{Emil Durkheim: Society as Sacred}

According to Durkheim, something that seems to be a true characteristic of beliefs and rituals is not the supernatural element, but the concept about 'the sacred'. The world of religion is categorized into both sacred and profane areas. The sacred things are considered as superior, omnipotent, forbidden from any normal relations and deserving of the utmost reverence. Whereas the profane things are common, uninteresting and can be taken for granted. Therefore, according to Durkheim, religion is a system of belief and practice related with sacred things. ${ }^{5}$

A society is a dynamic system which always changes over time as a function of development.. The development has lead society towards a changes from something simple to be more complex. The complexity and modernity resulted in waning norms in public life. In line with this, then religion takes part in giving meaning and purpose in people's lives.

Durkheim also focused on social solidarity (cohesiveness). He distinguishes two types of social solidarity, namely mechanical and organic solidarity. Mechanical solidarity operates in traditional society, whilst organic solidarity normally occurs in modern society. Durkheim states that traditional societies are typically small-scale and cohesive because every one hold same values. They havesimple division of labor, and relies on underdeveloped technology. All hunters within hunting and gathering society use the same type of weapons, for

${ }_{5}^{5}$ Emil Durkheim, The Elementary Forms of the Religious Life, translated by Josept Ward Swain (New York: Macmillan Company, 1915), p. 47. 
example, and all peasant farmers plant crops in the same way. Because everyone participates in the same social life within the same culture, they come to share the same values. It is these shared, nearly identical values that hold society together. Durkheim called this type of solidarity mechanical solidarity. ${ }^{6}$

In industrial societies, on the other hand, people perform specialized tasks using complex tools, and they seldom interact with others directly. Although people share some values, they disagree on many others.. Durkheim pointed out that the differences among modern people make them interdependent. For example, the assembly line workers the Ford company in California do not interact with the accountants at Ford headquarters in Michigan. Yet they are interdependent. If the accountants do not perform their jobs, then the assembly line workers will not get paid; and if the assembly line workers fall behind, the Ford will not meet its production schedules and the accontants might be out of work.In this way, if one fails, all fail; and if one succeeds, all succeed. Durkheim called this types of solidarity as organic solidarity. Durkheim assumed that society, like a plant or animal, consist of systems that act together to maintain the life of the organism. Contemporary functionalists no longer rely on this assumption, but they do say that the parts of a social system work together to maintain the cohesion of the system. ${ }^{7}$

Religion itself is social system created by its followers which is pivoted on non-empirical powers that they believe and utilize to reach salvation. ${ }^{8}$ In another word, it means that religion can give meaning and provide guidance for humanity. Religion always provides moral guidance to human beings. Moreover, religion can unite people in one moral community. According to Durkheim, religion is not belief in High God or gods, but rather a unified system of beliefs and practices based upon a classification of social reality into sacred and profane things. Furthermore these beliefs and practices mite its adherents in a single moral community.

\footnotetext{
${ }^{6}$ Emil Durkheim, The Division of Labor in Society (Glencoe: Free Press, 1893/1960), p. 25.

7 Tim Curry at. al., Sociology For The Twenty-First Century (New Jersey: Prentice Hall, 1996), p. 12.

${ }^{8}$ Hendropuspito, Sosiologi Agama (Yogyakarta: Kanisius, 1983), p. 34.
} 
Religion survives because it satisfies a basic social function, not a psychological one. Thus Durkheim argued that 'No society can exist that does not feel the need at regular intervals to sustain and reaffirm the collective feelings and ideas that constitute its unity and its personality. In this sense there are no false or irrational religions, because religion is the self-representation of society that is its collective representation. ${ }^{?}$

For Durkheim, the collective and emotional character classificatory practices in modern society has broken down and, as a result, with modernity there is more indeterminacy of belief. Individuals can become more reflextive about classificatory principles, because they are subject to a proces of individualisation ${ }^{10}$. With regards to this, Turner argued:

We can reconstruct Durkheim's argument to think about two abstract types society. In pre-modern societies, the social world is thick and sticky; it is difficult to join social groups without rites of passage and considerable ritualistic effort, such as entering a sweat lodge and having visions. Sticky societies are even more difficult to leave than to join; attempts to leave the society (such as apostasy) may be punished by the threat of violence, if not death. In modern societies, membership of social group in a civil society tend to be voluntary and people come and go according to their own preferences. Membership is fluid rather than fixed. Correspondingly, in pre-modern societies, beliefs are not held on an individual but on a collective basis, and individuals can neither exercise choice when it comes to endorsing collective beliefs nor can they easily change membership of their social group, which is normally determined by gender and age. ${ }^{11}$

Durkheim's concept of religion and solidarity is basically categorized as functionalist perspective, also called functionalism. Functionalism argues that society creates behavioral patterns which consist of norms that are legitimate and are binding its members; each part (institution) is tightly dependent on the other so that changes in one part will influence other parts and the whole system as well.

\footnotetext{
${ }_{9}^{9}$ Durkheim, The Elementary Forms, p. 322.

${ }^{10}$ Bryan S. Turner, Religion and Modern Society, Citizenship, Secularisation and the State (New York: Cambridge University Press, 2011), p. 40

${ }^{11}$ Ibid.
} 
The functionalist theory sees religion as one of the social institutions which holds an essential role in dealing with the basic needs of the society. This theory states that religion as a dominant social cause in the formation of social segments (strata) within the society, in which each has its own feeling that is capable to unite people within a compact uniting place, but is the religious feeling differs, this can make a group to be different and separated from one another. ${ }^{12}$

Fungsionalist theorists also assume that society maintains itself in a state of equilibrium (balance)that permits it to operate efficiently. The equilibrium may be upset, however, for any number of reason. External circumstances such as war, trade imbalances, or catastrophes of nature can cause the equilibrium to falter and then fail entirely. Internal threats to equilibrium also exist. For example, as industrialization advanced, the family lost its economic role and domestic life was thrown into chaos for a time. Functionalist theorists further believe that societal cohesion derives from consensus and common values. People in US, to illustrate, be live strongly in the values of individual effort and hard work. These common values strengthen the cohesion of Americansociety because people of different ethnic groups, religion, and regions are drawn together in common beliefs that surpass their differences.

As a formal theory, functionalism has four basic premises: first, society is a system, that is a whole comprising interdependent parts; second, this systemic whole comes before the parts, meaning that one cannot understand any single part (that is cultural beliefs, legal institution, social patterns of family organisation, political institutions, or economic/technological organisations) except by referring it to the larger systemic whole of which it forms a part; third, understanding a part by referring it to the whole by seeing that part as performing a function for the maintenance and the equilibrium of the whole. Thus the relationship between the parts and the wholes is a functional relationship; the fourth premise is the most important thing for our purposes here, it is logical derivative of the first and the third. The interdependence of the parts is itself a functional interdependence, the parts are mutually supportive of each other, mutually compatible with

${ }^{12}$ Durkheim, The Elementary Forms, p. 95. 
each other, and it is precisely in this mutual compatibility that they serve to maintain the whole. ${ }^{13}$

\section{Tahlilan as Shari' $a$ Teaching and Culture}

The root word of tahlilan is tablil wich carries a sacred or theological meaning. Tahlil means saying Là ilāha illa Allăh; a creed of acceptance that there is no God but Allah. Traditional Muslim groups consider tablilan as an activity which has a theological meaning because within tablilan activity, there is creed declearing belief or acceptance in the oneness of God; that there is no other God but Allah. The phrase Là iläha illa Allāh is spoken repeatedly. There are also a plea for forgiveness for themselves and for others and other readings closely related with religious morality. In tablilan people often recite several verses of al-Qur'an, such as sura Yasin. ${ }^{14}$ Therefore, those who strongly support the tradition of tablilan have the reason to say that it is a religious activity.

On the other hand, tablilan is perceived as a cultural and social activity as it is culturally constructed and carried out differently from one area to another. In addition, it does not have any ground and evidence in Holy Qur'an and Sunnah. Tablilan has been viewed as a form of Hindu tradition which has been modified, and has been filled with Islamic nuances.

There is a difficulty in differentiating between tablilan as a religious activity and as a socio-cultural activity. This is because in fact that both socio-cultural activities and religious rituals are inseparable from one another, ${ }^{15}$ as Geertz says that "religion is a cultural system."16

13 Ankie M. M. Hoogvelt, The Sociology of Developing Societies (London: The Macmillan Press Ltd., 1976), pp. 51-52.

14 Tablilan, viewed from its reading, consists of two elements, 'syarat' and 'rukun' readings, syarat means the readings of: Sura al-Ikblas; Sura al-Falaq; Sura an-Nas; Sura alBaqarah verses 1 to 5; Sura al-Baqarah verse 163; Sura al-Baqarah verse 255; Sura alBaqarah from verse 284 to 286; Sura al-Ahzab verse 33; Sura al-Ahzab verse 56; and readings in the middle of Shalawat, Istighfar, Tahlil dan Tasbih. Whereas the readings referred to as rukun tahlil are: Sura al-Baqarah verse 286; Sura al-Hudayat 73; Shalawat Nabi; Istighfar; Kalimat Thayyibah; Tasbih. It is unknown who arranged the sequence of readings in the tablilan tradition, but nobody rejects it. The sequence seems to offer a technical solution, that is, to facilitate those who are still beginners. Read Madchan Anies, Tablil dan Kenduri Tradisi Santri dan Kiai, Mahbub Djamaluddin (ed.) (Yogyakarta: Pustaka Pesantren \& LKiS, 2009), p. 104.

${ }^{15}$ Daniel L. Pals, "Society as Sacred: Emil Durkheim," in Seven Theories of Religion (New York: Oxford University Press, 1996), p. 88. 
A social system or a social pattern is always under change, even those which are based on religion. Some people decide not to perform certain rituals such as tablilan, which is considered as a heresy (bid'ab), even when a lot of people perform the same thing, then the existing patterns on proper religious concepts in the society has changed. Therefore, it can be understood that someone considers tablilan as a religious teaching or a sacred.

On the contrary, when someone has deep understanding that tablilan is as a cultural production, it is possible that the person would continue performing tablilan or leave it behind without feeling any burden. With regards to this, tablilan is considered as a profane activity, which has no correlation with theology or sacred thing. ${ }^{17}$ This activity is meant to strengthen social solidarity. If social solidarity as the basis and the motivation of people to do tablilan, then it can be assumed that this tradition will not survive in a relatively long time, because it will be like other profane activities developed by modern society. Thus, tablilan tradition no longer takes place based on mere mechanic solidarity, as Durkheim said, but it also has mixed organic solidarity, because Kotagede, for example, is a transition from a traditional society to a modern society. The emergence of social attachment in this area is not based on the existence of each person's specialization, as usually the case in a modern society, but the specialization here is still in the form of function and role of each member. This, for example, can be seen in the interdependence between religious leaders, citizens, and local leaders (Rukun Tetangga/Neighborhood Association or Rukun Warga/Community Association), or local leaders and religious leaders.

\section{Kotagede and Its Society}

Kotagedeis one of districts of Yogyakarta. It has an area of 3.07 square kilometer; this $9.45 \%$ of the area of special region of Yogyakarta. The topography of Kotagede is dominated by residential areas and farmlands. Kotagede is divided into three sub districts:

\footnotetext{
${ }^{16}$ C. Geertz, The interpretation of Culture (New York: Basic Book, 1973), p. 190.

${ }^{17}$ Everybody is free to decide whether a thing or an activity is considered sacred of profane. Just like other functional spheres, therefore, religion is potencially applicable to everything. Just as anything can be commodified or politicized, so anything, as Durkheim stated, can be sacralized. Peter Beyer, Religion and Globalization (London: SAGE Publication Ltd., 1994), p. 102.
} 
Prenggan, Purbayan, and Rejowinangun. The center of economy area is Kotagede Market. Around the market there are several historical and cultural sites of Islamic Mataram Kingdom. To the west of Kotagede Market there is a kampong named Alun-alun, and to the west of this kampong there is an area believed as the remnabts of the first Mataram Palace.

According to Atmosudiro, ${ }^{18} \mathrm{Ki}$ Ageng Pemanahan (the first king of Mataram) was a figure who has an important role in the formation of Kotagede residence. He changed Mentaok Forest into a residence and into a city. Mentaok Forest was bestowed by the Sultan of Pajang to Ki Ageng Pemanahan and Ki Penjawi because they defeated and killed Arya Penangsang, an enemy of Pajang Kingdom. Initially, Mataram Kingdom remained under the control of Pajang Kingdom, and then by Ki Ageng Pemanahan, it was handed over to his son, named Sutawijaya as the second king of Mataram. Sutawijaya built a wall surrounding the kingdom to strengthen Mataram area. After Sutawijaya defeated the Kingdom of Pajang, and held the title "Senapati Ing Alaga Sayidin Panatagama," Kotagede was then designated as the center of the government of Mataram Kingdom. Under the rule of Sutawijaya, Mataram Kingdom expanded its power over many areas in Java. Sutawijaya was buried in Makam Agung Kotagede. ${ }^{19}$

Kotagede serves as a center of economic, social and cultural activities under the rule of Sutawijaya government. It can be seen from the terms used in Kotagede, such as Pasar Gede. 'Pasar' (market) is the center economy and commerce, and 'Gede' (big) is the scale of its activity, as the center commerce. Kotagede is also well known as the center of silver crafts and other crafts, until present time. Kotagede, established in the $16^{\text {th }}$ century, was one of the cities in Java which adopted the principle of "Catur Gatra Tunggal", the application of four components in unison. The four elements are the castle/palace, the mosque, the town square, and the market. The palace, as the city center, is surrounded by a fort and moat. These components were built gradually starting from the residences, including the palace followed by

\footnotetext{
${ }^{18}$ Sumijati Atmosudiro, "Tata Ruang Permukiman Kota Gede Kuna dan Orang Kalang dalam Perspektif Profesionalisme Pekerjaan," Jurnal Kebudayaan Kabanaran 3, Januari 1, 2002, pp. 124-129.

${ }^{19}$ H.J. Van Mook, Kuta Gede, translated by LIPI and KITLV Leiden (Jakarta: Bhratara, 1972), p.12.
} 
other core components successively: the fort with moats, the Grand Mosque, the park and the cemetery.

The concept of "Catur Gatra Tunggal" exploits the principle of four main components of the city, the palace as the center of the city, the town square as the public space, located to the north of the palace. The mosque as the center of worship activity, located to the west of the palace. The market as the center of economic activity, located to the north east of the fort surrounded palace. Although many have left their initial functions, the old components can still be seen from the toponym of the city available now. The town square has become a dense residential area. The palace building has become a cemetery and surrounded by people's houses (now it is referred to as Kampung Kedhaton), and the city center is no longer the palace, but the market.

Of the four main components of the city, only remaining the Grand Mosque and the market. The other heritages that can still be seen are the Mataram Royal Cemetery and Sendang Seliran. The Kotagede's uniqueness can be seen from the historical buildings displaying traditional architecture and narrow alleys, including accidental alleys formed by the lines of houses. The houses in Kotagede were built hundred years ago. It proves that Kotagede has long possessed the high skills to build distinctive traditional houses.

Kotagede has te characteristics of Islamic kingdom city in Java. The architecture style of traditional Javanese houses and Kalang houses also shape the physical features of Kotagede area as an area with Javanese character. The main streets of Kotagede are Mondorakan Street, Kemasan Street, Karanglo Street, Tegalgendhu Street and Watu Cantheng Street. Each of these streets is approximately six meters in width. Among these streets, Mondorakan Street and Kemasan Street still have the typical characteristics of Kotagede. They are dominated by shop-houses along their sides. Some of the house owners are radical Islamic reformist figures who do not believe in the principles of macro-cosmos of a building; therefore, the orientation of buildings no longer follow the rules of macro-cosmos and micro-cosmos of traditional Javanese houses, which observe north-south orientation. All the shop-houses along the main streets are facing the streets..$^{20}$

20 Revianto Budi Santosa, Kota Gede Life Between Walls (Jakarta: Gramedia Pustaka Utama, 2007), p. 25. 
The main streets have the typical of façade rhythm which is formed by repetitive opening forms, created by house windows and doors. The displays show a mixture of Dutch and traditional Javanese architecture. The line of shop-houses along the main street of Mondorakan shows one of the typical characteristics of shop-houses in Kotagede. In its development, the shop-house line expands to Kemasan Street and along Karanglo Street. Shop-houses owned by wealthy businessmen are familiar views found in Kotagede.

The spread of ancient Kotagede residences can be traced back based on the toponym which centers at the palace as the residence of the king and the center of government, and the market as the center of economy. What is meant by toponym is the names of places. According to Atmosudiro, there are several toponyms related to the profession and the status of the residents. The toponym which represents status is oriented to the palace, whereas the toponym which related to the profession tends to be oriented to the market. The grouping of society based on the status and profession such as craftsmen, priest, officer, etc. Their position refers to the service in catering the king's or the society's needs. Therefore, the placement of residences is adjusted to the function being held. ${ }^{21}$

Here are the names of kampongs based on the status and profession of their residences: (1) Name of kampongs based on the status of the residents, that is, a place for royalties, such as Kampong Prenggan, which means the kampong where Prince Pringgoloyo (the seventh child of Panembahan Senapati) lives; or Kampong Bumen, the kampong where Pangeran Mangkubumi (Panembahan Senapati's brother) lives; (2) Name of kampongs based on the profession of the residents, such as Kampong Pandheyan, which means the kampong where blacksmiths live; Kampong Samakan, which means the kampong where leather tanners live; Kampong Mranggen, which means the kampong where craftsmen who create sheaths for keris and spears, or carvings live; Kampong Jagalan, which means the kampong where livestock (such as cows, buffalos, goats) butchers live.

\section{Kotagede Society's Value System}

The value system means a form of faith which serves as a basis for the society to understand the reality, called a life view. Just like Javanese societies in general, the life view of Kotagede society is not

${ }^{21}$ Atmosudiro, 'Tata Ruang, p. 40. 
solely religion, but also the view about humans' life and their culture. It is inaccurate to say that all Kotagede society has a characteristic of syncretism, because only a small portion of them holds the view. This is because Muhammadiyah has brought a deep influence towards the religious attitudes of the society. Therefore, the term tantularism spirit is more appropriately given to Kotagede society, because the more dominant features are characteristics of Javanese culture which is religious, non-doctrinaire, accommodative, and even tolerant towards various differences within. ${ }^{22}$

Based on the statistics data about religions in Kotagede, most, which is $93 \%$, of the society embraces Islam. The society is even well known as a religious one among societies in Yogyakarta. Kotagede society is also known as a modernist society, because it is the center of Muhammadiyah in Yogyakarta, aside from Kauman Kampong which is located in the center of Yogyakarta.

Yet, it doesn't mean that Kotagede society is totally clean from mystical thoughts, such as believing in mystical things, performing pilgrimage to cemeteries of people who are considered sacred, with an intention that their wishes be granted, believing in the powers of the ancestors, especially the late kings and the late priests. This system of thoughts is still found among people living in kampongs such as Singosaren, Pondongan, Gedongan, Bumen, Pilahan, Prenggan and Kalang, ${ }^{23}$ which is currently referred to as Tegalgendhu area. Almost all

22 Tantularism is a term applied to show the spirit of fusion which is based on or which originates from the teachings of Empu Tantular in his manuscript 'Kakawin Sutasoma': "Bhinneka Tunggal Ika Tan Hana Dharma Mangrawa", which literally means "even with various appellation given, God is one, and there no second truth." Empu Tantular's words clearly express not only the oneness of God, but also the oneness of the truth. This is where the spirit of tantularism lies, the spirit which encompasses the core of the Javanese views of life. Such a spirit not only inspires and excites Javanese religiosity, but also all other aspects and elements of Javanese culture. It is the tantularism foundation which serves as the base of all Javanese positive life attitudes, not syncretism, as many experts of Javanese culture concluded earlier. Aulia, Ritual Puasa Orang Jawa (Yogyakarta: Narasi, 2009), p. 26.

23 Special for kalang people, a community of craftsmen in Kotagede, they had little different tradition from others in the death ceremony. Historically, they were brought from Bali Island by Senopati, the ruler of Mataram Kingdom. Culturally, kalang people had tendency to Hinduism. Rituals from the 3rd day ceremony until the 2nd year ceremony were similar to the rituals of other community. Howeve, for the 1000th day ceremony kalang people had special ritual, it was kalangobong ceremony. Kalangobong was a ceremony of cremation of wooden doll, whereas the corpse had been buried one year before. This ritual remembers us to the cremation ceremony in Bali called ngaben. 
of these areas are occupied by modernist Islamic society (Muhammadiyah).

Further, in those area, there are still some people who support traditional Islam, based on the simplicity of their religious attitudes. For instance, in Prenggan, for example, which is a kampong predominantly occupied by Muhammadiyah followers, there has been a pesantren whose religious belief is traditional, or which is affiliated to Nahdlatul Ulama, that is, Pondok Pesantren Nurul Ummah.

In addition, Kotagede culture as a subculture of Javanese culture has long been the life view and life attitude of Kotagede people. The life attitudes of Kotagede people have a dominant identity and character which is still based on guidance from ancestors passed on from generation to generation, respect to others and various symbol in their expressions, becoming their art and cultural spirit.

Therefore, most people in Kotagede try to mix various Islamic concepts and way of thinking with the original local views, especially the world's natural existence and the supernatural realm. For example, $\mathrm{n}$ certain kampongs in Kotagede, we can still find strong Javanese tradition such as the tradition to prepare for death, birth, and certain occupationwhich is usually initialized with a ritual called wilujengan/sugengan/slametan. This ritual is performed as a means to plead to God that the commencement of the work will be granted with safety and ease. This ritual is also used as a means for social interaction, giving information to the neighbors about the planned activity/work, and asking for their approval and prayers. Usually, this ritual is accompanied with offerings in the form of a complete tumpeng rice, with all its accompanying condiments, ingkung (cooked whole chicken), 'raja' banana, various market snacks, etc. Normally, the higher the social level who organizes such an event, the more complete the sesaji (offering) prepared.

\section{Tahlilan in Kotagede Society}

Kotagede society, just like any other common Javanese society, has a lot of ceremonies or customs that are still practiced and kept until today. Almost all aspects and events of the society's life have a certain ritual. Despite the passage of time, these rituals are not left behind,

Kalangobong ceremony was held in the yard, and the sawdust was stored in the middle senthong room. 
including tablilan. Many people in Kotagede still believe that the dead still need the prayers from of those who are still alive in order to get peace in the afterlife. ${ }^{24}$.

Tablilan in Kotagede has been going on for years. The tradition can still be found in this area because the local community still believes that there is a connection between them and the deceased, especially close family (clan) members. The belief about deceased family member's spirit, which is merged with the belief in natural power, that has an influence on humans' life, becomes the main characteristics or special features in the religious life and custom of Kotagede community, namely syncretism, tantularism, and kejawen which are tolerant and accommodative. According to their belief, the tablil prayers can grant their wishes, can be helpful for deceased as well as living family members. This deep-rooted belief is considered having an impact on society's way of thinking. ${ }^{25}$

However, not all people in Kotagede perform tablilan. Some of them no longer believe that tablilan is as a religious teaching. Therefore they do not practice it for the commemoration of the death of their family member. ${ }^{26}$ Nevertheless, some communities, such as people in kampong Cokroyudan, although do not perform tablilan for the death of a family member, they replace it with tadarusan, ${ }^{27}$ this is reciting the verses of al-Qur'an together, specifically surat Yasin and continued by saying prayers for the deceased.28

As far as we can observe, there are three events related to tablilan in Kotagede. First, official events to commemorate sacred days related with the cemetery in Kotagede; second, construction of a new residence or house; and third, events related with death. In regards with events related to the death, the counting of the days begins with the day a person passes away. Tablilan is performed in the first night of death. Usually, on the third day, tablilan, accompanied by a communal

\footnotetext{
${ }^{24}$ Interview with Bapak Mukadi.

25 Interview with Bapak Mukadi, a community figure and an expert on culture of Kotagede, he resides in Kampong Cokroyudan, Kotagede.

${ }^{26}$ Interview with Bapak Zuwana, a religious figure who often leads tadarusan al-Qur'an in Kampong Cokroyudan, Kotagede.

27 Tadarusan is derived from the Arabic word darasa, which literally means 'to read'. The word is then generally used by the community to refer to activities of reading the verses of al-Qur'an.

${ }^{28}$ Interview with Bapak Mukadi.
} 
feast (selamatan), is performed (nelung dina), after that, on the seventh day (mitung dina), and then on the fortieth day (matang pulub dina), and then on the one hundredth day (nyatus dina), after that commemorating the first anniversary (nyetabun), and finally on the one thousandth day (nyewn). The local community still believes that three days after people passed away, the spirit or soul of the deceased still resides inside the house. It will leave but still lingers around the house until the seventh day. Later, on the fortieth day, the spirit of the deceased moves away from the house, leaving the family behind. On one hundredth day and later, people believe that the soul is already in the spirit world. However, nowdays only a few people believe and practice it.. Most people now hold tablilan only until the fortieth day after the death. ${ }^{29}$

Tablil is usually performed at night after maghrib prayer ( $b a^{\prime} d a$ maghrib). Before organizing a tablil, the host invites neighbors and relatives. The host usually ask someone to invite (ngatur-atur) the neighbors, ,then tablilan is conducted at that night. However, in certain kampongs, tablilan is performed without sending invitations. In this case, tablilan is held spontaneously because everybody knows the tradition, especially the night after the deceased was buried. Only the time is determined, either after maghrib prayer or after isya. Before tablilan starts, while waiting for the others come, the guests are served with drink (sweet tea) and snacks. After everybody comes, tablilan begins with a welcoming remark by a member of the family, who later hands over the handling of the event to the local religious figure, commonly called as kaum. ${ }^{30}$ The event goes on with reciting surat Yaasin and followed by reciting the tablil, and after that, reciting the

\footnotetext{
${ }^{29}$ Interview with several community members who support tahlilan in Kotagede. If further studied, the chronology of the sacred days can be found in Sunan Kalijaga's teachings, contained in Suluk Linglung verses 61-66, pupub Kinanthi. However, as expressed by Chodjim, in its further development, the ceremony may have been reduced into a mere ceremonial formality. It no longer has a substance, it is all just cover. Achmad Chodjim, Sunan Kalijaga, Mistik dan Makrifat (Jakarta: Serambi, 2015), p. 272 and p. 297.

${ }^{30}$ In general Javanese society, a kaum is a revered figure because his immense function and role in the society, both in social and religious knowledge aspects, they generally also are relatively older in age. There is a slight difference about the concept of kaum among Kotagede society, here, kaum means someone who is often requested to lead religious ceremonies, even though he may be still very young in age.
} 
closing prayers. ${ }^{31}$ After tablilan ends, the kaum who lead the ceremony thanks the audience and takes leave to go home. Upon leaving, the guests are given berkatan in the form of rice accompanied with spices and condiments packed in paper boxes. These berkat boxes were prepared earlier by the host. Sometimes, some nearby neighbors come to help cooking and preparing the berkat. Neighbors normally donate basic necessities, such as rice or vegetables, to the person hosting the event.

Tablilan tradition can be viewed in the perspective of sociology which emphasizes the aspects of behavior, in this case, as a custom or habit performed regularly according to specific time and need. The tradition also facilitates Kotagede society to express the values they hold and to show social solidarity through participation in the prayers that they perform for families who invite them.

\section{Emotion versus Ritual in Tahlilan}

Several decades ago, A. M. Hocart spelled out at the length the idea that ritual and emotion are mutually antipathetic, that ritual is an "intellectual construction that is liable to be broken up by emotion". 32 In this case, this idea fitted neatly into the some of the Muslims' attitude toward "enthusiastic religion, the emotional expression of Muslims which shows their irrational behaviors in performing a religious ritual.

The community who performs tablilan in Kotagede, for example, seems to experience a very deep emotional state. This is evident when they recite the tablil verses under the guidance of a religious leader (kaum), they sit quietly and solemnly. Most of the participants close their eyes for full concentration; some sit with faces down, some recite the tablil loudly, while others recite them softly. No overly religious behaviors are shown during a tablilan ceremony is being done, some participants even can be seensitting quietly throughout the service. ${ }^{33}$ The impression created by the tablilan event emerges from casual (profane) up to sacred (theological) behaviors full of solemn

\footnotetext{
${ }^{31}$ Not all tahlil tradition is opened by the reading of Sura Yasin. It all depends on the request by the host.

32 AM. Hocart, "Ritual and Emotion," A.M Hocart, The Life-giving Myth, edited by Lord Ragian (London: Methuen, 1952), p. 61.

${ }^{33}$ Result of an observation on a tablilan ceremony on a Thursday evening, which took place in one of the kampongs in Kotagede.
} 
expressions. Following what Paul Radin said, such an activity can manifest in various forms, there can be just an ordinary feeling, there can be joy, there can be excitement, there can be passion and solemnness, and there also can be a deep drowning feeling. ${ }^{34}$

It seems that deep emotional involvement is necessary; it is even stipulated in a tablilan ceremony. If not, then tablilan activity carries no profound spiritual value. In this context, F. Schleiter said "if we have to perform such a ritual in sacred ceremonies, then we are expected to be in a condition of mental disarray, because if not, then our mind will tell us that the activity is objectively fruitless. ${ }^{35}$

Conforming to this view, tablilan performed in various areas of Kotagede can still happen and it is also joined by members of modernist Islamic group like many of the members of Muhammadiyah. ${ }^{36}$ For members of Muhammadiyah who participate in tablilan, it seems that the event only functions sociologically, not much emotion is involved there. It can be seen from the expression of participants during tablilan is quite varied; some look solemn while others look just usual. Therefore, tablilan here can be perceived as both sacred and profane activity. So, as Durkheim said, the feeling of sadness, sorrow which is obviously emotional, is basically an indicator of their loyalty (to the deceased) and to fulfil a social obligation, and not an emotional condition, which may not present at all. ${ }^{37}$ This social obligation emerges because of strong solidarity and collectivity factors in the society. ${ }^{38}$

\footnotetext{
34 Paul Radin, The Ritual and Signifance of Winnebago Medicine Dance (Boston: n.p, 1911).

35 Frederick Schleiter, Religion and Culture, a Critical Survey of Methods of Approach to Religious Phenomena (New York: Columbia University Press, 1919), pp. 45-47.

36 The word 'modernism' applied to Muhammadiyah understanding of Islam as an opposite to the word 'traditional,' as expressed by Haidar Bagir, is not exactly the real meaning of the word 'modern' itself. Apart from the (limited) influence of modernization in the end of $19^{\text {th }}$ century up to the first half of the $20^{\text {th }}$ century, Islam layers are basically dominated by spiritualism, even pantheism (monistic) which emphasizes the unity among human, the nature and God. Haidar Bagir, "Islam dan Budaya Lokal," in Akhmad Sahal and Munawwir Aziz (eds), Islam Nusantara, (Bandung: Mizan, 2016), p. 178.

37 E.E Evans Pritchard, Theories of Primitive Religion (New York: Oxford University Press, 1965), p.75.

38 Durkheim's emphasis on solidarity and collective representations was in part the legacy of Comte's notion of 'the religion of humanity' and of French socialism. Read
} 
Yet, the meaning given in the preceding quotations to the word emotion is evidently something like sensation, that is, feeling that are not only spontaneous and ephemeral, but essentially internal and unique to each body. In this view, it is indeed difficul to envisage sensation becoming the objects of (ritual) concepts and thereby changing their essentially unique and ephemeral quality. Durkheim's Elementary Forms of the Religion Life has a more complicated account of the separation between the sensation and desires of the (individual) body, and the concepts and duties of the collective soul.

"It is quite true that the elements which serve to form the idea of the soul and those that enter into the representation of the body come from two different sources that are independent of one another. One sort are made up of the images and impressions coming from all parts of the organism; the others consist in the ideas ad sentiments which come from and express society. So the former are not derived from the latter. There really is a part of ourselves which is not placed in immediate dependence upon the organic factor: that is all that which represents society in us". 39

\section{Tahlilan Creates Solidarity}

Actually, the meaning of tablilan can be seen from both the religious and sosio-cultural aspects. Socially tablitan has a special meaning. It is the process of silaturrabmi or keeping in touch with each other. It aims to strengthen the bond among neighbors as well as to create brotherhood among members of society.

Kotagede people consider tablilan as an event where community members help each other to support the host to send prayers for a deceased family member. People will make the time to come to the tablilan when they are invited, because someday they will also hold tablilan when one of their family members passes away. However, if they cannot make it for certain reasons, they would ask one of their family members to representing him in the tablilan.

However several families no longer hold tablilan as they believe that it has no justifiable ground in the Islamic teaching. Nevertheless if they were invited they would come to attend for social solidarity reason. During tablilan, the local society will be united in a moral community. As stated in the theory of functionalism that a society

Andrew Wernick, August Comte and the Religion of Humanity, The Post-Theistic Program of French Social Theory (Cambridge: Cambridge University Press, 2001).

${ }^{39}$ Durkheim, The Elementary Forms, p. 271 
consists of many parts. Each part is tightly dependent to one another, therefore, a change happens on one part will influence other parts. The same case applies to the society who holds tablilan, although the members have different professions and different economic status, they actually need one another. Once people could be as the invitees, but at later they may be as the inviters. Today the neighbors will ask for help, but someday he would also ask for help the neighbors. The more fundamental function of tablilan from the belief of Kotagede society is to give a chance to each member to renew their commitment to the community, to remind them in the most solemnly way that they rely on their closest relatives, as their relatives rely on them and to encourage each individual to live together in a community.

Generally, social ethics is dominant in a tablilan. In Kotagede, tablilan can reproduce a common consensus, which is eventually used as a norm in the society. Actually, there is no penalty for someone who does not to attend a tablilan invitation, and no reward for someone who actively joins it. Nevertheless, because this activity is considered as a common norm, people will not arbitrarily skip attending the tablilan. Ninian Smart stated that: "A religious tradition or subtradition affirms not only a number of doctrines and myths but some ethical and often legal imperatives." 40

With regards to the tradition that inviting many people to gather, every house in Kotagede equipped for such a need. The house functioned not only for private and nuclear family space, but also for public space. The house is also a place for neighbours' activities. Therefore, the pattern of rooms at the houses would be influenced by the need of community activities such as spiritual tradition which was full of symbolic meanings. The interior of Javanese traditional houses in Kotagede could contain ceremonial meal rituals and respond to the symbolic meanings of ceremonial meal rituals by the form and hierarchy of rooms. ${ }^{41}$

In Kotagede society there is also another activity as part of tablil, Durkheim calls it as representation rite or remembrance rite. In this process, one of the details of the event is giving information by a

\footnotetext{
${ }^{40}$ Ninian Smart, Dimension of The Sacred An Anatomy of the World's Beliefs (Los Angeles: University of California Press, 1996), p. 11.

41 Adi Santosa, "Materialization Of Religious Ceremony System In The Interior Of Javanese Traditional Houses in Kotagede," 3th Internasional Seminar on Vernacular Architecture, Indonesia, March 2006.
} 
member of the family about his ancestors to the audience. The content of the information covers the function and role of the ancestors when they were still alive. The activity gives an impression of education, but basically it is still social activities.

In terms of social relations in Kotagede, the condition is slightly different with Durkheim's opinion. Durkheim said that in the modern era, social relations are based on mutual interdependence, because one individual cannot possibly generate a good product without the skill of others. In Kotagede the social relations are generally not based on personal profession, but based on the relation of function and role..

For example in the context of tablilan, four components of the society are always present in such an event: those who support tablilan, those who refuse tablilan, religious figures, and formal leaders of the society, such as RT (neighborhood association), RW (community association) and LKMD (village level association). Sociologically, these four elements depend on one another to perform their own functions. Any kind of association, either social, religious, or cultural, is normally used by society leaders as a powerful place for social media. Most of the formal leaders of Kotagede society no longer accept tablilan as a religious activity, they even consider tablilan as a heresy. However, these leaders would still attend tablilan, because by attending such an event, his function and role will be strengthened, especially as the guardian of the people. Through this kind of activity, a leader can show his existence as a figure who understands the needs of people. The leader's motivation in attending tablilan is to communicate and to show his self-existence in front of the people. Therefore, in almost all tablilan activities, a society leader usually sits next to the religious figure who leads the tablilan. These two elements become the reference for every people in any kinds of thing over time.

People in Kotagede live in a society where Islamic law is dominant. Basically, based on religious ideology, Kotagede society consists of two groups, those who support tablilan and those who oppose it. However, they believe that the principle of harmony must be prioritized over religious laws or norms. Sociologically, they arrange their interactions through two principles: harmony and respect, ${ }^{42}$ where open conflicts must be avoided. Magnis Suseno said that from the principles of

42 Suwardi Endraswara, Etika Hidup Orang Jawa, Pedoman Beretika dalam Menjalani Kebidupan Sehari-hari (Yogyakarta: Narasi, 2010), p. 14. 
harmony and respect we create life harmony. ${ }^{43}$ Therefore, although some of them, including some of Islamic preachers, admit that tablilan has no ground in the teaching of Islam, they would attend tablilan for the friend or social relations.

Further, the ethical implications is still the most important things. The standpoint is that principles of harmony demand something from the individuals. Kotagede people demand that their efforts to guarantee their own interests and rights should not disturb social harmony. The principles of harmony principally forbid the taking of a position which will create conflict. The principles of respect forbid the taking of a position which defies the desired attitudes of respect. Whatever is expected and and attempted by individuals, whatever type of rights he tries to hold in the society, whatever religious norms that he believes, Kotagede people expect that each individual acts according to their own consideration, as long as the principles of harmony are withheld and hierarchical degrees are still respected. Therefore, the principles of harmony contain an absolute prohibition on efforts to act only based on one's awareness and will.

Geertz, as quoted by Afendy Widayat, stated that there are two most determining rules of interaction in Javanese society. The first that in every situation, humans should act in such a way that conflict is avoided. The second that when communicating and interacting, one must always shows respect towards others according to their level and position. ${ }^{44}$

In the context of tablilan tradition in Kotagede, these two rules can actually explain why this tradition can survive. Society's participation in performing this tradition could be motivated by their cultural values of harmony as conveyed in the expression "crah agawe bubrah, rukun agawe santosa" which literally means that conflict will create chaos, while harmony will create strength. It is said that yen pengin diajeni ya ajenana wong liya which literally means that if you want respect from others, you

\footnotetext{
${ }^{43}$ Frans Magnis Suseno, Etika Jawa: Sebuah Analisa Falsafi tentang Kebijaksanaan Hidup (Jakarta: PT. Gramedia, 1984), p. 38.

44 Afendy Widayat, "Toleransi dalam Ungkapan Tradisional Jawa," Kejawen Jurnal Kebudayaan Jawa, Volume 1, Nomor 1, Jurusan Pendidikan Bahasa Daerah Fakultas Bahasa Seni Universitas Negeri Yogyakarta in cooperation with Penerbit Narasi Yogyakarta, p. 67.
} 
must respect others, which also called as concept of tolerance. ${ }^{45}$ Harmony and respect are evident when Kotagede society can satisfy and please the others by participating in prayers and giving other forms of moral support, especially those who are suffering a loss, and also those who are enjoying happiness. Pleasing others is an attitude by which someone shows respect to others and avoid open confrontation. Although frequently others' opinion who agree that tablilan can be performed is against one's own opinion, he would still participate in tablilan, or if he decided not to get involved, he would give a certain more rational excuse and try not to hurt the feeling of the person who gives the invitation. It is clear that theological issues, such as saying that tablilan is a heresy, can be defeated by sociological and functional matters.

\section{Conclusion}

Tablilan, as a tradition in the society, is still preserved until now, this is caused by several factors. First, Kotagede society live in an era of transition from a traditional to a modern society. The people's value system in the transitional era such as Kotagede enables tablilan to enjoy a fertile area to flourish. The power of normative modernist Islamic doctrine which forbids tablilan is not stronger than the society's system of thoughts, which has been mystical since the very beginning. Second, the educated people tend to consider tablilan as a profane culture. Its sociological functions have strengthened this tradition to remain present in the society until now. Meanwhile, the society who has long believed that tablilan tradition is a product of Islamic religion will enjoy it even more as their spiritual consumption. Third, the strength of tablilan tradition is also seen when this tradition can freely be understood, be given meaning, be re-interpreted, or even be modified by the society to fit their own beliefs, after all, there is no standard regulation regarding its content structure and reading.

For those who believe that tablilan is a product of religious teaching, they can feel the spiritual aspects of this ritual, and therefore, he would get a solemn feeling when performing it. While those who think that tablilan is cultural tradition, they may view it as a means to show his existence and participation in togetherness and to strengthen the bond and unity of brotherhood in the society. []

45 Niels Mulder, Individual and Society in Java (Pribadi dan Masyarakat di Jawa) (Jakarta: Pustaka Sinar Harapan, 1996), p. 23. 


\section{References}

\section{Books and Articles}

Anies, Madchan. Tablil dan Kenduri, Tradisi Santri dan Kiai. Mahbub Djamaluddin (ed.). Yogyakarta: Pustaka Pesantren-LkiS, 2009.

Atmosudiro, Sumijati. "Tata Ruang Permukiman Kota Gede Kuna dan Orang Kalang dalam Perspektif Profesionalisme Pekerjaan." Jurnal Kebudayaan Kabanaran 3, Januari, 2002.

Beyer, Peter. Religion and Globalization. London: SAGE Publication Ltd., 1994.

Chodjim, Achmad. Sunan Kalijaga, Mistik dan Makrifat. Jakarta; Serambi, 2015.

Curry, Tim at al. Sociology For The Twenty-First Century. New Jersey: Prentice Hall, 1996.

Denny, Frederick M. "Islamic Ritual Perspective and Theories." in Richard C. Martin (ed.). Approaches to Islam in Religious Studies. Tucson: The University of Arizona Press, 1985.

Durkheim, Emil. The Division of Labor in Society. Glencoe: Free Press, 1893/1960.

-. The Elementary Forms of the Religious Life. Translated by Josept Ward Swain. New York: Macmillan Company, 1915.

Fattah, Muhammad Abdul. Tradisi Orang-Orang NU. Yogyakarta: Pustaka Pesantren, 2012.

Geertz, C. The interpretation of Culture. New York: Basic Book, 1973.

Haris, Ahmad. Bid'ab dalam Literatur Islam. Jambi: Referensi, 2007.

Hendropuspito. Sosiologi Agama. Yogyakarta: Kanisius, 1983.

Hocart, AM. "Ritual and Emotion." in A.M Hocart, The Life-giving Myth, edited by Lord Ragian. London: Methuen, 1952.

Hoogvelt, Ankie M. M. The Sociology of Developing Societies. London: The Macmillan Press Ltd., 1976.

Mook, H.J. Van. Kuta Gede, translated by LIPI and KITLV Leiden. Jakarta: Bhratara, 1972. 
Nakamura, Mitsuo. The Crescent Arises over the Banyan Tree, a study of the Muhammadiyah Movement in a Central Javaness Town, c. 1910-2010, 2nd Enlarged Edition. Singapore: ISEAS, 2012.

Pals, Daniel L. "Society as Sacred: Emil Durkheim." in Seven Theories of Religion. New York: Oxford University Press, 1996.

Pritchard, E.E Evans. Theories of Primitive Religion. New York: Oxford University Press, 1965.

Radin, Paul. The Ritual and Signifance of Winnebago Medicine Dance. Boston: n.p., 1911.

Sahal, Akhmad and Munawwir Aziz (eds). Islam Nusantara. Bandung: Mizan, 2016.

Santosa, Adi. "Materialization Of Religious Ceremony System In The Interior Of Javanese Traditional Houses In Kotagede." 3th Internasional Seminar on Vernacular Architecture, Indonesia, March 2006.

Santosa, Revianto Budi. Kota Gede Life Between Walls. Jakarta: Gramedia Pustaka Utama, 2007.

Schleiter, Frederick. Religion and Culture, a Critical Survey of Methods of Approach to Religious Phenomena. New York: Columbia University Press, 1919.

Smart, Ninian. Dimension of The Sacred An Anatomy of the World's Beliefs. Los Angeles: University of California Press, 1996.

Streng, Fredrick J. at al. Ways of Being Religius readings for a new approach to religion. New Jersey: Prentice-Hall, Inc., 1973.

Turner, Bryan S. Religion and Modern Society, Citizenship, Secularisation and the State. New York: Cambridge University Press, 2011.

Wernick, Andrew. August Comte and the Religion of Humanity, The PostTheistic Program of French Social Theory. Cambridge University Press, 2001. 